Dr. Adamson says be rarely cures a case of sycosis barbæ or of acne vulgaris. I very rarely fail to do so. I may say the same of gonorrhoea, gleet, and lupus. These last three are practically always mixed infections, so that a single antigen is not likely to succeed. 1 have had the most rapid and dramatic results in two cases of paratyphoid $B$ and three of $B$. typhosus infection, but again not with the specific antigen alone; it is necessary to include the patient's $B$. coli as well.

As to the dangers of abnormal reaction they are chimerical, as they can be controlled by the exhibition of iodine.

I ask Dr. Adamson to read my book "Therapeutic Immunisation" and to try again. I shall be much surprised if he does not get greatly improved results. I always feel myself that if $I$ fail it is generally my own fault, that $I$ have missed some essential microbe or that $I$ have failed to adapt my immunisation to the reactivity of the patient. I am not so foolish as to think that the use of vaccines preciudes the use of other methods of treatment, on the contrary; but I know that by its means results can be attained which can be obtained by no other known method.

I am, Sir, yours faithfully,

University College, Dublin, August 17th, 1918. W. M. Crofton.

\section{TRANSIENT HEMIPLEGIA.}

\section{To the Editor of THE L A NOET.}

SIR, - Enjoying a brief holiday, I have only just read the clinical note and your annotation upon my case of transient hemiplegia. The cerebro-spinal fluid was not examined, as owing to the rapid recovery of the patient to a condition of good health one dia not feel justified in pursuing a very active investigation. There are none of the usual evidences of arterio-sclerosis, although an interesting cardiac condition was verified by autopsy in the patient's father, who died at a comparatively early age.

If I may say so, this case illustrates fully the need of a bețter coördination of work, happily called "team-work" by Sir Bertrand Dawson in his recent and most opportune manifesto. Many of his suggestions were published in the memorandum of the London Local Medical and Panel Committee in June, 1917. Those ideas were dominant in the minds of those who, in 1912, urged the profession to accept the modified terms of the National Insurance Act as a first great instalment of State coöperation, as applied to civilian medical services. The principle of mutual aid which the words "team-work" so happily express seems to me the only hope for both humanity and civilisation.

I am, Sir, yours faithfully,

Studland, Dorset, August 20th, 1908.

$$
\text { H. H. Mills. }
$$

\section{A NEW REFLEX SIGN IN SPASTIC PARAPLEGIA.}

\section{To the Editor of TEE LANCET.}

Sir,-In THE LANCET of June 1st last, on p. 777, there appeared an editorial note under the above heading. The sign has been described recently by Dr. Bing, the neurologist of Basle, and consists of plantar flexion of the arkle when the dorsum of the foot is struck at any point along an imaginary line between the malleoli. It is stated that the sign occurs constantly in organic spastic conditions of the lower extremities, and that Dr. Bing claims that this "paradoxical" Achilles jerk can be elicited in cases in which the more common reflex signs of spasticity from corticospinal impairment appear to be absent.

Since June lst $I$ have made a point of testing this sigr in every one of a large number of patients and I have found that, whereas it is certainly present in the conditions mentioned above, it is present also in cases of non-organic disease in which the tendon-jerks are exaggerated, and also in a considerable proportion of cases which, to my examination, are neurologically normal.

The matter can readily be tested by everyone for himself. and $I$ think that it will be found that the sign has nor quite the significance which has been claimed for it by its distinguished describer and by the author of your note. I am, sir, yours faithfully,

HILDRED CARLILL, M.A., M.D., M.R.C.P.

Neurologist to the Royal Navy; Assistant Physician,

R.N. Hospital, Haslar, August 17th, 1918 .

\section{đIbe gatar.}

The Casualty List.

THe following medical officers appear among the casualties announced since our last issue :-

$$
\text { Killed. }
$$

Capt. W. H. Lister, D.S.O., M.C., with bars, R.A.M.C., was a student at University College, London, and qualified in 1913. At the time of the outbreak of war he was holding an appointment at University College, which he at once resigned, and joined up. He saw service in France and in Italy, in which latter country he was killed. In the Balkan War he served as a dresser in the British Red Cross Unit with the Greek army, for which he was awarded the Balkan Medal. The awards of the D.S.O., the M.C., and bars were recorded in THE LANCET respectively of June 26th, 1915, p. 1373; Oct. 28th, 1916, p. 770 ; Dec. 2nd, 1916, p. 595 ; and Dec. 22nd, 1917, p. 951 .

Capt. G. H. H. Almond, R.A.M.C., received his education at Loretto, at Oxford, and at St. Bartholomew's Hospital, London, and qualified in 1906 . After holding appointments at St. Bartholomew's Hospital and at the West London Hospital, he practised at Bath, where he was honorary assistant pathologist at the Royal United and Mineral Water Hospitals. He served in the Sonth African War in a combatant capacity.

Lieut.Col. A. J. A. Menzies, D.S.O., R.A.M.C., qualified at Ediaburgh in 1912, and joined the R.A.M.C. prior to the outbreak of war. At the time of his death he was in command of a cavalry field ambulance. The award of the D.S.O. was recorded in THE LANCET of Nov. 13th, 1915 , p. 1112 .

Capt. W. H. Lloyd, R.A.M.C., attached London Regiment, was a student at the Middlesex Hospital, London, and qualified in 1915. He joined up shortly afterwards.

Surg. L. A. Martin, R.N., was a student at University College Hospital, London, and qualified in 1912.

Previously Reported Missing, now believed Killed.

Capt. C. W. Bond, R.A.M.C., was a student at St. Mary's Hospital, Paddington, and qualified in 1901. A few years later he qualified in dentistry from the Royal Dental Hospital, London. He took part in the Boer War.

$$
\text { Died of Wounds. }
$$

Capt. R. C. Rogers, R.A.M.C., attached H.A.C., qualified at Edinburgh at the close of the year 1914. He held an appointment at the Royal Infirmary in that city prior to joining up.

Capt. M. A. McKechnie, Canadian A.M.C.

Capt. T. Whitmore, Canadian A.M.C.

Wounded.

Lieut.-Col. D. Donald, Cahadian A.M.C.

Major J. Hughston, R.A.M.C.

Capt. I. M. Barrow, Australian A.M.C.

Capt. D. St. C. Campbell, Canadian A.M.C.

Capt. E. A. MoCusker, Canadian A.M.C.

Capt. J. D. H. W. Barnett, Canadian A.M.C.

Capt. D. A. Morrison, Canadian A.M.C.

Capt. J. A. C. Scott, M.C., R.A.M.C., attd. Durham L.I.

Wounded and Prisoner in Gierman Hands.

Capt. G. Perkins, P.A.M.C.

\section{Previously reported Killed, now reported Prisoner in} German Hands.

Lieut. A. M. Ulare, R.A.M.C., attached Durham L.I.

Previously reported Missing, nov reported Prisoners in German Hands.

Lieut.-Col. A. C. H. Gray, R.A.M.C.

Capt. R. M. Handfield-Jones, M.C., R.A.M.C.

Casualties among the Sons of Medioal Men.

The following additional casualties among the sons of medical men are reported:-

Second Lieut. J. H. Wybrants, London Regiment, died of wounds, only son of the late Dr. R. B. Wybrants, of Wincanton, Somerset.

Temp. Capt. T. P. Muspratt, M.C., Worcestershire Regiment, died of wounds, second son of Dr. C. D. Muspratt, of Bournemouth.

Eient. (acting Major) R. H. Collyns, M.E., Royal Engineers, died of wounds, second son of Dr. R. G. Collyns, of Dulverton, Somerset. 